\title{
The Determinants of Health Consultation Utilization among HIV Patients at Budi Kemuliaan Hospital, Batam, Indonesia
}

\author{
Dawiyah Siregar'), Juanita'), R. Kintoko Rochadi²) \\ 1) Department of Administration and Health Policy, Universitas Sumatera Utara \\ 2)Department of Health Promotion and Behavior, Universitas Sumatera Utara
}

\begin{abstract}
Background: HIV and AIDS is a global public health problem. Until the end of 2016, there were more than 36.7 million people living with HIV. HIV \& AIDS counseling is a confidential communication between clients and counselors aimed at increasing the ability to deal with stress and make decisions regarding HIV \& AIDS. The purpose of this study was to determine the effect of the ability to pay and the environmental factor on consultation health service utilization at Budi Kemuliaan hospital, Batam.

Subjects and Method: This was a cross sectional study was conducted at Budi Kemuliaan Hospital, Batam, from May 8 to June 18, 2018. A sample of 76 HIV patients was selected by systematic random sampling. The dependent variable was the use of consulting service. The independent variables were risk of illness and environment. The data were collected using questionnaires and analyzed by a multiple logistic regression.

Results: The use of consultation health service was influenced by the risk of illness (OR $=6.82 ; \mathrm{p}$ $=0.011)$ and supportive environment $(\mathrm{OR}=4.59 ; \mathrm{p}=0.028)$.

Conclusions: The use of consultation services is influenced by risk factors for illness and the environment.
\end{abstract}

Keywords: consultation service, the risk of illness, environment, HIV/AIDS patient

\section{Correspondence:}

Dawiyah Siregar. Department of Administration and Health Policy. Universitas Sumatera Utara, Jl. Universitas No.32, Padang Bulan, Medan Baru, Medan, North Sumatera 20222.

Email: dawiyahsrg@gmail.com. Mobile: +6281267500608

\begin{abstract}
BACKGROUND
Health is a human right and is one of the elements of prosperity that must be realized in accordance with the ideals of the Indonesian people which are referred to in Pancasila and the 1945 Constitution (Health Law Number 39 of 2009). Therefore, optimal health for all citizens of Indonesia is something that must be achieved.
\end{abstract}

Human Immuno-deficiency Virus (HIV) is a type of virus that attacks or infects white blood cells that can cause a decrease in the immunity of the human body. Aquired Immune Deficiency Syndrome (AIDS) is a set of symptoms of a disease that arises due to a decrease in the immune system caused by a virus.

HIV and AIDS is a global public health problem. Until the end of 2016, there were more than 36.7 million people living with HIV. The number continues to increase until now so it becomes a formidable challenge to achieve sustainable development goals (SDGs) until 2030. In the third goal, namely good health, one of the targets in point 3.3 is to end the AIDS epidemic. The results of the 19th ASEAN Summit meeting in November 2011 were used to mobilize ASEAN Heads of State / Government to express their commitment to the goal of "ASEAN with Zero new HIV Infection, Zero Discrimination and Zero 
HIV Related Deaths" which translates to "There are no new infections, no discrimination, no deaths from AIDS" in 2015.

In 2013, of the world's total population, there were 35 million people living with HIV including 16 million women and 3.2 million children aged $<15$ years. The number of new HIV infections in 2013 was 2.1 million consisting of 1.9 million adults and 240,000 children aged $<15$ years. The number of deaths due to AIDS was 1.5 million, consisting of 1.3 million adults and 190,000 children aged <15 years (Ministry of Health RI, 2014). HIV/AIDS in Indonesia was first discovered in the province of Bali in 1987. Until now HIV/ AIDS has spread in 386 districts/cities in all provinces in Indonesia. The highest number of HIV sufferers from DKI Jakarta Province is 45,355 , accounting for 31,429 people from East Java Province and 24,725 people from Papua Province. The highest number of AIDS sufferers is East Java Province, namely 16,911 people and Papua Province for about 13,398 people. The top 10 cases of HIV are in DKI Jakarta, East Java, Papua, West Java, Bali, North Sumatera, Central Java, West Kalimantan, Riau Islands, and South Sulawesi. The number of HIV sufferers in Riau Islands Province as of September 2014 was 4,555 people.

Riau Islands Province is a transit area for the spread of HIV and AIDS and drug trafficking, as well as sexual transactions, because it is directly adjacent to Singapore and Malaysia. This geographical location causes the number of people with HIV and HIV sufferers to continue to increase. HIV / AIDS in Batam was first discovered on September 6, 1992 on Babi Island (Dutch Amat Island) which is a former area of localization. Babi Island is located in the middle of the sea, not large and located not far from Pulau Belakang Padang. This means that prostitution in Batam does not only spread in the city center but also to the border. In preventing HIV/AIDS transmission, Batam Health Office is very disciplined in the obligation to use condom.

HIV \& AIDS counseling is a confidential communication (building trust) between clients and counselors aimed at increasing the ability to deal with stress and make decisions related to HIV \& AIDS. The counseling process includes evaluating personal risk of HIV transmission, facilitating behavioral prevention and selfadjustment evaluation when clients face positive test results (Admin, 2017). One of the Voluntary Counseling Test (VCT) clinics in Batam City is located at Bina Kemerdekaan Hospital (RSBK).

Zschock said that someone with a higher formal education will have better health knowledge and information on health services and will ultimately influence a person in utilizing better health services according to their needs. In addition to this, another factor that affects a person in the utilization of health services is the cost of services. Zschock (1979) in Ilyas (2006) states that the cost of health services is strongly related to the level of utilization of health services.

This study aimed to analyze the determinants of health consultation utilization among HIV patients at Budi Kemuliaan Hospital, Batam, Indonesia.

\section{SUBJECT AND METHOD \\ 1. Study Design \\ The type of the research in this analytical study was cross sectional design.}

\section{Population and Sample}

The study was conducted at Budi Kemuliaan Hospital, Batam, from May 8 to June 18, 2018. The study population was HIV patients who were recorded at Budi Kemuliaan Hospital. A total of $76 \mathrm{HIV}$ 
Journal of Health Policy and Management (2018), 3(2): 76-80

https://doi.org/10.26911/thejhpm.2018.03.02.03

patients was selected using purposive random sampling.

\section{Study Variables}

The dependent variable was the use of consultation service. The independent variables were the risk of illness and environment.

\section{Data Analysis}

Univariate analysis was conducted to determine the average, standard deviation, minimum, and maximum scores. Bivariate analysis using chi-square test aimed to examine the relationship between indepen- dent variables and the dependent variable of the study. Multivariate analysis using a multiple logistic regression.

\section{Data Collection}

The data were collected by questionnaire.

\section{RESULTS}

\section{Analisis Univariat}

Characteristic of the study subjects including gender, age, education, employment status, and income were described in Table 1.

Table 1. Characteristic of the study subjects

\begin{tabular}{|c|c|c|}
\hline Characteristics & $\mathbf{n}$ & $\%$ \\
\hline \multicolumn{3}{|l|}{ Age } \\
\hline 15-30 years old & 30 & 39.5 \\
\hline 31-50 years old & 46 & 60.5 \\
\hline \multicolumn{3}{|l|}{ Gender } \\
\hline Male & 42 & $55 \cdot 3$ \\
\hline Female & 34 & 44.7 \\
\hline \multicolumn{3}{|l|}{ Education } \\
\hline Do not go to school & 13 & 17.1 \\
\hline Primary school & 17 & 22.4 \\
\hline Junior high school & 24 & 31.6 \\
\hline Senior high school & 12 & 15.8 \\
\hline Diploma & 6 & $7 \cdot 9$ \\
\hline Graduate & 3 & $3 \cdot 9$ \\
\hline Post graduate & 1 & 1.3 \\
\hline \multicolumn{3}{|l|}{ Employment } \\
\hline House Wife & 3 & $3 \cdot 9$ \\
\hline Farmer & 4 & $5 \cdot 3$ \\
\hline Laborer & 11 & 14.5 \\
\hline Private Employee & 13 & 17.1 \\
\hline Student & 7 & 9.2 \\
\hline Trader & 3 & 3.9 \\
\hline Entrepreneur & 7 & 9.2 \\
\hline Civil Servants & 2 & 2.6 \\
\hline Commercial Sex Workers & 26 & 34.2 \\
\hline \multicolumn{3}{|l|}{ Income } \\
\hline$<1$ Million & 16 & 21.1 \\
\hline 1-3 Million & 34 & 44.7 \\
\hline 3- 5 Million & 13 & 17.1 \\
\hline$>5$ Million & 13 & 17.1 \\
\hline \multicolumn{3}{|l|}{ Ability to Pay the Consultation Fee } \\
\hline$<\operatorname{Rp} 100,000$ & 28 & 36.8 \\
\hline $\operatorname{Rp} 100,000-\operatorname{Rp} 150,000$ & 34 & 44.7 \\
\hline$\geq$ Rp150,ooo & 14 & 18.4 \\
\hline
\end{tabular}


2. Bivariate Analysis

Bivariate analysis was conducted to determine the relationship of independent variables with the dependent variable, namely age, gender, education, risk of illness, and environment.

Table 2. The Results of Bivariate Analysis by Using Chi Square

\begin{tabular}{|c|c|c|c|c|c|c|c|}
\hline \multirow[t]{2}{*}{ Variable } & \multicolumn{4}{|c|}{ Consultation Service } & \multirow{2}{*}{$\mathbf{N}$} & \multirow{2}{*}{$\%$} & \multirow[b]{2}{*}{$\mathbf{p}$} \\
\hline & No & $\%$ & Yes & $\%$ & & & \\
\hline \multicolumn{8}{|l|}{ Age } \\
\hline 15-30 Years Old & 7 & 23.3 & 23 & 76.6 & 30 & 100 & \multirow{2}{*}{0.020} \\
\hline 31-5o Years Old & 23 & 50 & 23 & 50 & 46 & 100 & \\
\hline \multicolumn{8}{|l|}{ The Risk of Illness } \\
\hline Not Risky & 7 & 19.4 & 29 & 80.6 & 36 & 100 & \multirow[t]{2}{*}{0.001} \\
\hline Risky & 23 & 57.5 & 17 & 42.5 & 40 & 100 & \\
\hline \multicolumn{8}{|l|}{ Environment } \\
\hline Good Environment & 11 & 25.6 & 32 & 74.4 & 43 & 100 & \multirow[t]{2}{*}{0.003} \\
\hline Bad Environment & 19 & 57.6 & 14 & 42.4 & 33 & 100 & \\
\hline
\end{tabular}

\section{Multivariate Analysis}

Table 3. The Results of Multivariate Logistic Regression Analysis

\begin{tabular}{|c|c|c|}
\hline Variable & OR & $\mathbf{p}$ \\
\hline Age & 0.32 & 0.113 \\
\hline Gender & 1.25 & 0.722 \\
\hline The Risk of Illness & 6.82 & 0.010 \\
\hline Environment & 4.59 & 0.040 \\
\hline
\end{tabular}

\section{DISCUSSIONS}

$\overline{\text { The use of consultation in this study was }}$ the activity of HIV patients to choose whether to use the health consultation service or not. The results of this study showed that 30 HIV patients (39.5\%) did not utilize consultation services and 46 people (60.5\%) used the consultation services.

Based on the results of the study, age was one of the factors that affect the use of consultation services among HIV patients at Budi Kemuliaan Hospital, Batam. Age was related to the maturity of thinking, so that the older the age of the patients, the better the perception toward the importance of the consultation service. The result of this study was in line with Husnul (2015).

Based on bivariate testing conducted by the researchers, it was found that from the 40 respondents (100\%) who have less risk of illness, 17 respondents (42.5\%) used the consultation services, while from the 36 respondents (100\%) who had a good risk of illness, 29 respondents (80.6\%) utilized the consultation services.

\section{The Relationship Between Living Environment of HIV Patients and the Use of Consultation Service}

A study done by Handayani (2017) showed that stigma and discrimination were born from negative views of certain people or groups who were considered to have something that was bad. This stigma made PLWHA felt guilty easily and accepted the rejection from surrounding environment. Discrimination could occur in communities around the residence and at work.

Based on the results of the study, it was found that $33 \mathrm{HIV}$ patients (43.4\%) lived in a less supportive environment and 43 HIV patients (56.6\%) lived in a supportive environment.

The results of qualitative research conducted by Fadilla (2014) concluded that HIV/AIDS sufferers often experienced physical and psychological disorders due to 
side effects of drugs consumed. The use of consultation services from the hospital could help the HIV patients to know and control the proper procedure of taking the medicine. In addition, consultation was also beneficial to provide support for HIV patients to regularly carry out their treatments.

\section{The Relationship Between the Risk of Illness and the Use of Consult- ation Service}

The results of this study indicated that the level of the risk of illness has a positive and significant effect on the utilization of consultation services.

A study done by Oedojo (2007) revealed that the HIV/AIDS epidemic was currently not only a health problem, but also in various aspects of human life. The spread and impact of HIV/AIDS was felt by all levels of society.

\section{REFERENCES}

$\overline{\text { Admin (2017). Kaum Gay Dominan, Pen- }}$ derita HIV/AIDS Batam Tembus 8.101 Orang, 698 Meninggal. https://batampos.co.id/2017/12/o4/kaumgay-dominan-penderita-hiv-aids-batam-tembus-8-101-orang-698-meninggal/.
(2017). Pemeriksaan Laboratorium dapat Ditanggung Oleh BPJS Kesehatan. http://www.pasienbpjs.com/2017/04/pemeriksaan-laboratoriumditanggung-bpjs.html

(2018). Layanan Konseling HIV \& AIDS. http://blog.angsamerah.com/layanan-konseling-hivaids/

Ashari RM, Nurhayani (2013). Permintaan (Demand) Masyarakat Terhadap Pemanfaatan Asuransi Kesehatan Di Pt. Asuransi Jiwa Inhealth Makassar. Makassar: FKM UNHAS

Azwar A (1996). Menjaga Mutu Pelayanan Kesehatan. Sinar Harapan: Jakarta.

Bappeda Karimun (2014). Bab II Evaluasi Hasil Pelaksanaan RKPD Tahun 2014 dan Capaian Kinerja Penyelenggaraan Pemerintahan. bappeda.karimunkab.go.id/

Depkes RI (1997). Upaya Peningkatan Mutu Pelayanan Rumah Sakit, Pusat Pendidikan dan Pelatihan Pegawai, Jakarta.

(1998). Petunjuk Pelaksanaan Indikator Mutu Pelayanan Rumah Sakit Direktoral Jendral Pelayana Medik, WHO Departemen Kesehatan RI, Jakarta.

(2000). Paradigma Baru Pelayanan Kesehatan Indonesia, Jakarta 